Article

\title{
Crop Diversity and Common Agricultural Policy-The Case of Slovakia
}

\author{
Jarmila Lazíková ${ }^{1, *}$, Anna Bandlerová ${ }^{1}$, Luubica Rumanovská ${ }^{2}$, Ivan Takáč ${ }^{2}$ (1) \\ and Zuzana Lazíková ${ }^{1}$ \\ 1 Department of Law, Slovak University of Agriculture in Nitra, 94976 Nitra, Slovakia; \\ anna.bandlerova@uniag.sk (A.B.); zuzana.lazikova@gmail.com (Z.L.) \\ 2 Department of European Policies, Slovak University of Agriculture in Nitra, 94976 Nitra, Slovakia; \\ lubica.rumanovska@uniag.sk (L'.R.); ivan.takac@uniag.sk (I.T.) \\ * Correspondence: jarmila.lazikova@uniag.sk
}

Received: 13 February 2019; Accepted: 1 March 2019; Published: 7 March 2019

\begin{abstract}
Crop diversity has an important role in sustainable agroecosystems. This study analyzed the crop diversity of agricultural holdings in particular regions (NUTS III) in Slovakia and identified the impact of Common Agricultural Policy (CAP) payments on the crop diversity of agricultural holdings. There are regional disparities in crop diversity in Slovakia. The highest crop diversity is typical for the regions with the best soil quality. From the results of econometric models, it was found that some of the CAP payments have an effect on crop diversity, mainly single area payment scheme (SAPS) payments, which had a negative effect, and payments for areas facing natural constraints (ANC) and animal welfare, which were found to have positive effects. It can be concluded that the second pillar of the CAP is able to improve or at least maintain crop diversity in Slovakia. Other important factors found to influence crop diversity are irrigation, total crop area corresponding with the farm size, geographical location including the soil quality, and the legal structure of agricultural holdings. However, the distance of the farm from the city, the education of managers, and membership in farmers' associations are not important factors for crop diversity in Slovakia.
\end{abstract}

Keywords: crop diversity; sustainability; agricultural holdings; Common Agricultural Policy; Slovakia

\section{Introduction}

The quality and diversity of European landscapes constitute a common resource and it is important to co-operate toward their protection, management, and planning [1]. The Convention defines a landscape as an area with a character that is the result of the action and interaction of natural and/or human factors [1], which provides semi-natural habitats for many endangered and rare species that are dependent on continued management for their preservation [2-5].

Agriculture is both a large-scale user of land and a provider of landscapes [6]. Many species and ecosystems of conservation concern in Europe depend on agricultural management [7]. In agricultural systems, crop biodiversity may provide the link between stress and resilience, as resilient agroecosystems are characterized by a high degree of crop diversity [8]. Crop diversification improves the capacity of agricultural systems and provides insurance or a buffer against environmental fluctuations because different species respond differently to change, leading to more predictable aggregate community or ecosystem properties [9]. More diverse cropping systems tune agroecosystem performance rather than less diverse systems [10]. Diversification is the sign of a progressive reorientation of agriculture toward a multifunctional activity that combines producing quality food, maintaining rural livelihoods and landscapes, promoting environmental stewardship, preserving biodiversity, and establishing improved agroecosystem function [11]. Moreover, diversification of 
the crops that the farmer produces may be an effective tool to help farmers deal with several types of risk [12]. Furthermore, crop diversity could play an important role in ecosystem resilience and in the agroecosystem; when rainfall is scarce, crop diversity can act as a catalyst for agricultural production [13].

At the end of the 20th century, many experts warned against the intensive form of agricultural production which caused many previously common species to become scarce or to disappear and caused a decline in semi-natural landscape elements [14-16]. The loss of biodiversity in agricultural landscapes reflected the strong environmental impact of European Union (EU) agricultural policy [3]. As a consequence, the priorities of the Common Agricultural Policy changed and measures were adopted to support the environmental aspects of land use (e.g., greening, agri-environmental-climate measures, and payments for ecological agriculture, including animal welfare), resulting from the fact that certain farming systems are particularly favorable for the environment such as extensive livestock, mixed systems, traditional permanent crop systems, or organic farming [17].The reformed Common Agricultural Policy (CAP) (2014-2020) promotes environmental conservation through three routes: cross compliance, greening payments, and agri-environmental schemes [18]. It includes three obligatory greening measures: ecological focus areas, maintaining permanent grassland, and crop diversification [19]. On the one hand, some hold a skeptical view of the CAP because the new environmental prescriptions are so diluted that they are unlikely to benefit biodiversity [20]. On the other hand, there is a hope that the agri-environmental schemes of the CAP will be central to the conservation of farmland biodiversity [21]. Moreover, they can be effective for conserving wildlife on farmland, but they are expensive and need to be carefully designed and targeted [7].

Capitanio et al. took into account the CAP variable as a ratio of the European first pillar of CAP support to total units of labor and dummy variables for the regimes of 2004-2006 and 2007-2010, demonstrating the existence of a positive relationship between CAP payments and diversity in Italy [22]. Chiron et al. created a model to describe the most likely changes in crop areas and included regional bird population data from the French Breeding Bird Survey. The authors concluded that farmland area and crop composition are important variables that drive bird abundance [23]. Renwick et al. analyzed agricultural and trade reform on land use across Europe, focusing on the issue of land abandonment. They noted that the overall impact of agriculture and trade reform on production within the EU is likely to be relatively small; however, a more disaggregated analysis highlighted more significant declines in particular countries, regions, and farm types, and showed that a loss of semi-natural farmland leads to a further decline in farmland biodiversity [24]. Reger et al. concluded that transfer payments are able to prevent the cessation of agricultural production; however, they have a tendency toward homogenization of the landscape [25]. Piorr et al. confirmed that, without direct payments, arable farming in marginal areas could not be maintained at all, and a loss of landscape and habitat diversity is contrary to the objectives of Natura 2000 [26]. According to Jambor and Harvey, the direct payments are not effective or justified and should be reduced or completely phased out. They should at least be converted into a safety net, while more radical reform requires greater conditionality on the practical "services" rendered by farmers to society. This implies that direct payments should be converted into a general contractual scheme, under which payments are made only to those delivering clear and measurable outcomes [27].

However, there are other factors affecting land-use intensity and diversity. Van der Sluis et al. showed the results of a logistic regression which underpins the importance of geographical context, farm size, and farmer type in the motivation for intensification or extensification. They added that the dominant pattern of stabilization which occurred over the past 10 years may also partly be a result of effective EU and national environmental and agricultural policies, which are increasingly concerned with improving environmental conditions in rural areas [28]. There is no expert common opinion with regard to how farm size affects production diversity. White and Irwin found that larger farms are more specialized [29]. However, other experts found strong indications of a positive relationship between diversification and farm size [30-34]. 
Moreover, Sichoongwe et al. identified other factors, such as technology, distance to the market, fertilizer quantity, and the geographical location of the farm, which affect the crop diversification in Zambia. On the other hand, factors such as gender, education, or the age of farmers, household size, the number of fields, and hired labor were not found to be statistically significant for crop diversification [34]. The research of similar crop diversification factors in Ethiopia proved that farm size, livestock assets, households with more male labor, and more fragmented farms with a larger number of different plots, the distance of the plot from the farm household, access to the market, and geographical location had significant effects on the diversification of cereal crops. On the other hand, age, gender, and the education of farmers had no significant relationship with the diversity of cereal crops [35]. However, Weiss and Briglauer argued that a significantly lower degree of diversification, as well as a stronger reduction in diversification over time, is also associated with businesses operated by older, less educated, part-time farm operators [33]. Farmers who participate in off-farm work, farms located near urban areas, and farms with higher debt-to-asset ratios are less likely to be diversified; on the other hand, there is a significant positive relationship between diversification and whether the farm business has crop insurance, is organized as a sole proprietorship, or receives any direct payments from current farm commodity programs [36]. Banerjee and Bhattachary argued that crop diversification helps maximize the utilization of scarce land resources, increase productivity, and reduce risk in agriculture [37]. Crop diversification is influenced by a number of infrastructural and technological factors such as the sustained supply of irrigation water, markets, fertilizer availability, proper roads, and transportation [38].

The main objective of this paper was to identify the impact of particular CAP payments on crop diversity in Slovakia. This study's econometric models were estimated from a survey of 530 agricultural holdings including family farms scattered throughout all regions (NUTS III) of Slovakia. The paper is organized as follows: the first section describes the development of landscape diversity and crop diversity in Slovakia after its accession to the EU. The second section includes an analysis of the crop diversity of agricultural holdings in particular regions (NUTS III) in Slovakia. The third section describes the three econometric models used to identify the impact of CAP payments (e.g., single area payment scheme (SAPS) payments, greening, payments for areas facing natural constraints (ANC), agri-environmental scheme payments, organic agriculture payments, and animal welfare payments) on the crop diversity of agricultural holdings in Slovakia.

\section{Data and Methods}

This study used data collected by the Ministry of Agriculture and Rural Development of Slovak Republic concerning agricultural holdings in 2015-2016. More than 600 agricultural holdings were assessed; however, only 527 were integrated into the model. The rest were excluded for various reasons (e.g., missing crop production or animal production data, data errors, missing data, or data outliers).

The crop diversity in Slovakia was quantified by calculating Shannon's equitability index for each agricultural business in our database. The Shannon's index is expressed as [39].

$$
H=-\sum_{i=1}^{s} p_{i} \ln \left(p_{i}\right)
$$

where $s$ is the number of crop species, and $p_{i}$ is the proportion of hectares of one particular species (n) divided by the total hectares of crop production $(\mathrm{N})$. Shannon's equitability index $\left(E_{H}\right)$ is computed as

$$
E_{H}=\frac{H}{H_{\max }}
$$

where $H$ is Shannon's diversity index, and $H_{\max }$ is calculated as $\ln (\mathrm{s})$. Shannon's equitability index assumes a value between 0 and 1 , with 1 being complete evenness. 
GRETL software was used to estimate the coefficients of the model by ordinary least squares (OLS) with heteroskedasticity assessed by the Breusch-Pagan test and censored regression model (TOBIT model) because of the censured dependent variable bordered by 0 and 1 . However, the estimated parameter results were changed minimally by using OLS and the TOBIT model.

The linear regression model is expressed as

$$
y_{j}=\alpha+\beta_{1} x_{1 j}+\beta_{2} x_{2 j}+\beta_{3} x_{3 j}+\beta_{4} x_{4 j}+\beta_{5} x_{5 j}+\beta_{6} x_{6 j}+\gamma x+\varepsilon_{j},
$$

where $y_{j}$ is the crop diversity index $(\mathrm{EH})$ of agricultural holding $j$ as a dependent variable, $\alpha$ is the intercept, $x_{1 j}$ is a single farm payment (SAPS), $x_{2 j}$ is a payment for greening, $x_{3 j}$ is a payment for less favorable areas (ANC), $x_{4 j}$ is an agri-environmental scheme (AES) payment, $x_{5 j}$ is a payment for organic agriculture (ECO), $x_{6 j}$ is a payment for animal welfare (WELFARE), $\beta_{1-6}$ express how many percentage points the crop diversity index changes by if a particular payment increases by one euro, $x$ is a vector of the control variables in the model with particular regression coefficients expressed as vector $\gamma$, and $\varepsilon_{j}$ represents residuals independent and identically distributed.

The vector of control variables consists of independent (explanatory) variables: region, legal structure of the holding, education of the manager, membership in farmers' associations, distance from the city, irrigated agricultural land, land used for ecological agriculture, the number of employees, total crop area, the share of revenue from agricultural (crops and animal) production in total revenue, the share of revenue from ecological agriculture in total revenue, total revenue share in the total costs, stock share in total costs, stock share in total revenue, and the share of revenue from the animal production share in the agricultural production revenue. The descriptive statistics of the described variables are shown in Table 1.

Table 1. Descriptive statistics.

\begin{tabular}{|c|c|c|c|c|c|c|}
\hline Variable & Description & Unit & Mean & $\begin{array}{l}\text { Standard } \\
\text { Deviation }\end{array}$ & Min & Max \\
\hline $\begin{array}{l}\text { Shannon's equitability } \\
\text { index }\end{array}$ & & & 0.490 & 0.154 & 0.065 & 0.846 \\
\hline SAPS & Single area payments 2015 & EUR & $85,879.393$ & $140,123.975$ & 0.000 & $1,117,737.000$ \\
\hline Greening & $\begin{array}{l}\text { Payments for sustainability and care } \\
\text { for natural resources } 2015\end{array}$ & EUR & $31,096.292$ & $58,598.845$ & 0.000 & $419,088.000$ \\
\hline ANC & $\begin{array}{l}\text { Less favored areas scheme payments } \\
\qquad 2015\end{array}$ & EUR & $16,052.284$ & $40,673.679$ & 0.000 & $433,247.000$ \\
\hline AES & Agri-environmental schemes 2015 & EUR & 3190.176 & $15,402.957$ & 0.000 & $166,932.000$ \\
\hline ECO & Payments for organic agriculture 2015 & EUR & 2757.444 & $18,902.151$ & 0.000 & $195,856.000$ \\
\hline WELFARE & $\begin{array}{l}\text { Payments for animal welfare } 2015 \\
\text { Distance of the agricultural holdings }\end{array}$ & EUR & 1775.634 & $11,826.597$ & 0.000 & $157,122.000$ \\
\hline Distance from the city & $\begin{array}{c}\text { from the district city } \\
\text { (LAU 1) }\end{array}$ & $\mathrm{km}$ & 12.797 & 13.764 & 1.000 & 67.300 \\
\hline Irrigated agricultural land & $\begin{array}{c}\text { Surface of irrigated agricultural land } \\
\text { area }\end{array}$ & ha & 15.890 & 91.112 & 0.000 & 960.000 \\
\hline $\begin{array}{l}\text { Land used for the organic } \\
\text { agriculture }\end{array}$ & $\begin{array}{c}\text { Agricultural land used for organic } \\
\text { farming }\end{array}$ & ha & 44.933 & 230.906 & 0.000 & 2950.740 \\
\hline Number of employees & Number of employees & & 13.448 & 27.130 & 0.000 & 236.000 \\
\hline Total crop area & $\begin{array}{l}\text { Agricultural land used for crop } \\
\text { production }\end{array}$ & ha & 480.845 & 689.378 & 5.000 & 4585.830 \\
\hline $\begin{array}{l}\text { Revenues from } \\
\text { agricultural (crops and } \\
\text { animal) production share } \\
\text { in total revenues }\end{array}$ & $\begin{array}{l}\text { Share of revenues from agricultural } \\
\text { production in total revenues } 2015\end{array}$ & $\%$ & 57.342 & 25.962 & 0.116 & 100.000 \\
\hline $\begin{array}{l}\text { Revenues from the } \\
\text { organic agriculture share } \\
\text { in total revenues }\end{array}$ & $\begin{array}{l}\text { Share of revenues from organic } \\
\text { farming in total revenues } 2015\end{array}$ & $\%$ & 0.188 & 1.624 & 0.000 & 22.447 \\
\hline $\begin{array}{l}\text { Total revenues share in } \\
\text { total costs }\end{array}$ & $\begin{array}{l}\text { Share of total revenues in total costs } \\
2015\end{array}$ & $\%$ & 70.027 & 146.123 & 0.000 & 2508.091 \\
\hline Stocks share in total costs & Share of stocks in total costs 2015 & $\%$ & 37.949 & 177.455 & 0.000 & 2752.598 \\
\hline $\begin{array}{l}\text { Stocks share in total } \\
\text { revenues }\end{array}$ & Share of stocks in total revenues 2015 & $\%$ & 26.913 & 50.904 & 0.000 & 998.472 \\
\hline $\begin{array}{l}\text { Revenues from the } \\
\text { animal production share } \\
\text { in revenues of the } \\
\text { agricultural production }\end{array}$ & $\begin{array}{l}\text { Share of revenues from animal } \\
\text { production in revenues from } \\
\text { agricultural production } 2015\end{array}$ & $\%$ & 16.280 & 29.766 & 0.000 & 100.000 \\
\hline
\end{tabular}


Table 1. Cont

\begin{tabular}{|c|c|c|c|c|c|}
\hline Variable & Description & Mean & $\begin{array}{l}\text { Standard } \\
\text { Deviation }\end{array}$ & Min & Max \\
\hline Region & $\begin{array}{r}\text { Dr } \\
\text { Brati } \\
\text { Trn } \\
\text { Trer } \\
\text { Ni } \\
\text { Žil } \\
\text { Banská } \\
\text { Pre } \\
\text { Ko }\end{array}$ & $\begin{array}{l}\text { variabl } \\
\text { region ( } \\
\text { gion }(\mathrm{T} \\
\text { gion (T } \\
\text { ion }(\mathrm{NI} \\
\text { gion ( } \mathrm{Z} \\
\text { ca regic } \\
\text { gion (P } \\
\text { gion }(\mathrm{K}\end{array}$ & & & \\
\hline Legal form & \multicolumn{5}{|c|}{$\begin{array}{c}\text { Dummy variable: } \\
\text { Business companies—benchmark legal form } \\
\text { Cooperatives } \\
\text { Individual farmer—a natural person doing business in agriculture }\end{array}$} \\
\hline Education & \multicolumn{5}{|c|}{$\begin{array}{c}\text { Manager only with agricultural experiences-benchmark education } \\
\text { Manager with some courses from agriculture } \\
\text { Manager with at least 2years of agricultural education } \\
\text { Manger with university education of agriculture, silviculture, veterinary, horticulture, or agricultural } \\
\text { engineering } \\
\text { Manager with university education outside of agriculture }\end{array}$} \\
\hline $\begin{array}{l}\text { Membership in the } \\
\text { farmers' associations }\end{array}$ & $\begin{array}{r}\text { Di } \\
\text { Non-member }\end{array}$ & $\begin{array}{l}\text { variabl } \\
\text { hmark } \\
\text { nber }\end{array}$ & ership & & \\
\hline
\end{tabular}

The economic variable and CAP payments for 2015 were taken into account to determine their impact on the crop diversity in 2016, as it was assumed that the CAP payments paid at the end of the particular year have a stronger impact on the crop diversity in the next year than the CAP payments paid at the end of the year when crop diversity was calculated. Similarly, a stronger impact from the economic results of the previous year on the crop diversity calculated in a particular year was assumed. A number of variables from the previous year (2015) were, therefore, taken into account to quantify their impact on the crop diversity in 2016.

In addition, regional disparities in the crop diversity were considered. A non-parametric test was used to assess the statistically significant differences because of the small number of agricultural holdings in some regions. The Kruskal-Wallis test was characterized as follows:

$$
H=\left(\frac{12}{N(N+1)} \cdot \sum_{j=1}^{k} \frac{R_{j}^{2}}{n_{j}}\right)-3 \cdot(N+1) .
$$

H-Kruskal-Wallis test characteristics

$\mathrm{N}$-Total number of agricultural holdings (all regions combined)

$R_{j}$-Rank total for each region

$n_{j}$-Number of agricultural holdings in each region

$k$-Number of regions

Additionally, identification of the pairs of regions with significant statistical differences was conducted by the multiple range test included in the Statgraphics Plus program.

\section{Results}

\subsection{Land Structure in Slovakia}

Slovakia occupies 4,903,435 ha, of which utilized agricultural land represents $39 \%$ of the territory. The land structure is documented in Figure 1. There were only minimum changes in the water and forest areas during the period under study. However, a significant increase was recorded in built-up areas to the prejudice of agricultural land. In 2001, agricultural land occupied $45.98 \%$ of the country; in 2016, it occupied only $39.13 \%$. 


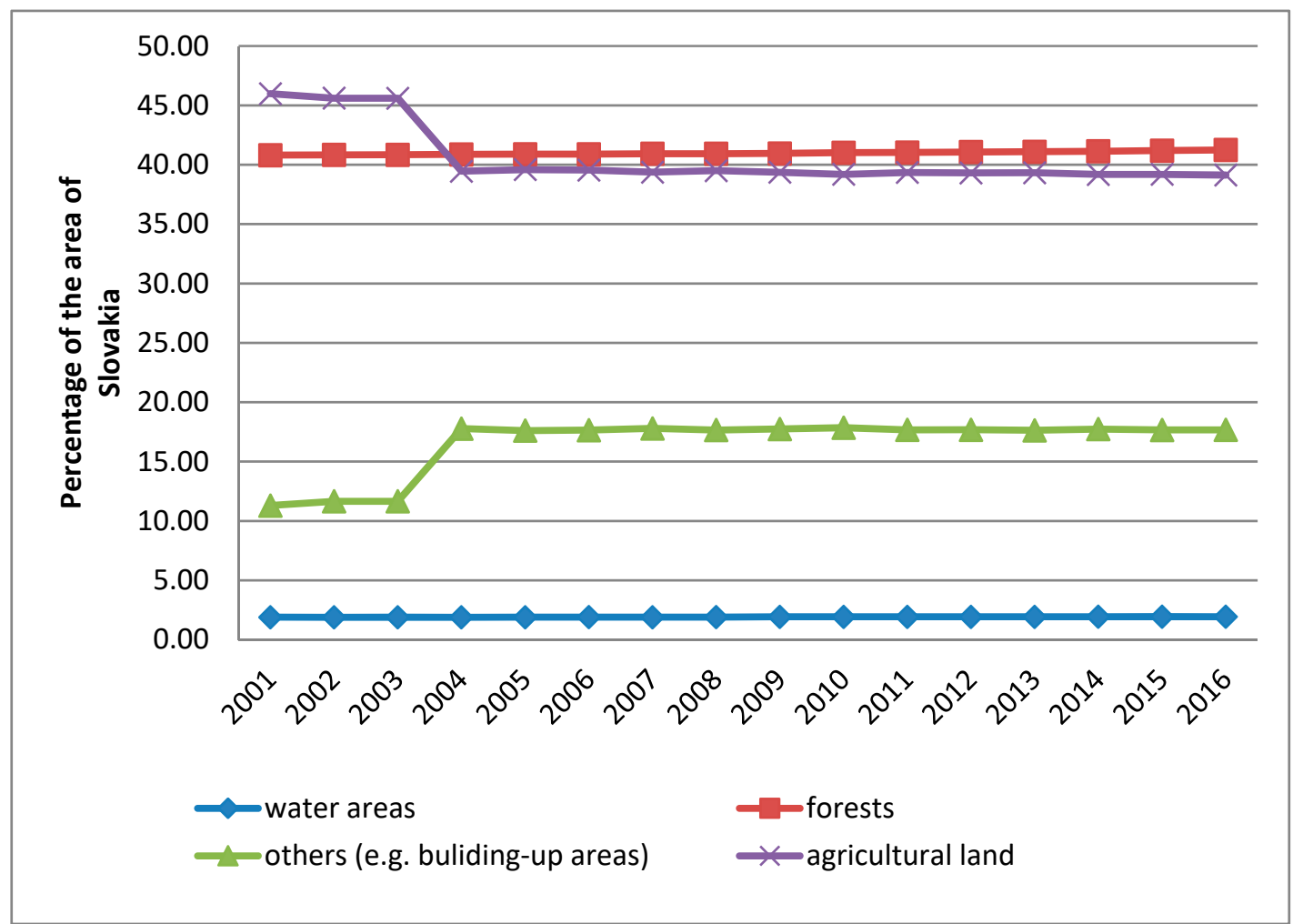

Figure 1. Development of the land structure in Slovakia 2001-2016.Source: own calculations on the basis of data from the Statistical Office of the Slovak Republic, 2017.

The agricultural land is cultivated mainly by agricultural holdings such as agricultural cooperatives and business companies. While individual farmers are the largest group of agricultural holdings, together they comprise the smallest share of agricultural land compared to the agricultural cooperatives and agricultural business companies. The individual farmers are interested in purchasing or renting more plots of land; however, the supply of land is too low. Most of the agricultural land is owned or rented by agricultural cooperatives and business companies that are not interested in giving up their land in favor of individual farmers as potential competitors. In spite of the insufficient supply of agricultural land, even greater areas of agricultural land are used for non-agricultural purposes (e.g., housing zones, industrial parks, and panels for solar energy). Moreover, the most fertile agricultural land in the country is used for these non-agricultural purposes. Unfortunately, the state government still prefers the foreign investors' interests in building up the industrial parks on the fertile low-lands near the capital city, to the detriment of the protection of agricultural land.

The structure of agricultural land includes arable land, permanent grasslands (pastures and meadows), permanent crops (e.g., vineyards, hops, fruit groves), and gardens. The arable land is approximately $70 \%$ of agricultural land, the meadows and pastures occupy approximately $27 \%$ of agricultural land, and the permanent crops and gardens occupy only approximately $3 \%$ of all agricultural land in Slovakia. However, the structure of agricultural land differs among the regions (NUTS III) of Slovakia. The structure of the particular regions is shown in Figure 2.

The most arable land is situated in the southwest regions of Slovakia such as the Bratislava region, the Trnava region, and the Nitra region. Furthermore, this land is the most fertile in the country. The permanent grasslands are typical for the uplands situated in central and north Slovakia, such as the Žilina region, the Prešov region, and the Banská Bystrica region. In these regions, the arable land has the poorest soil quality in Slovakia. 


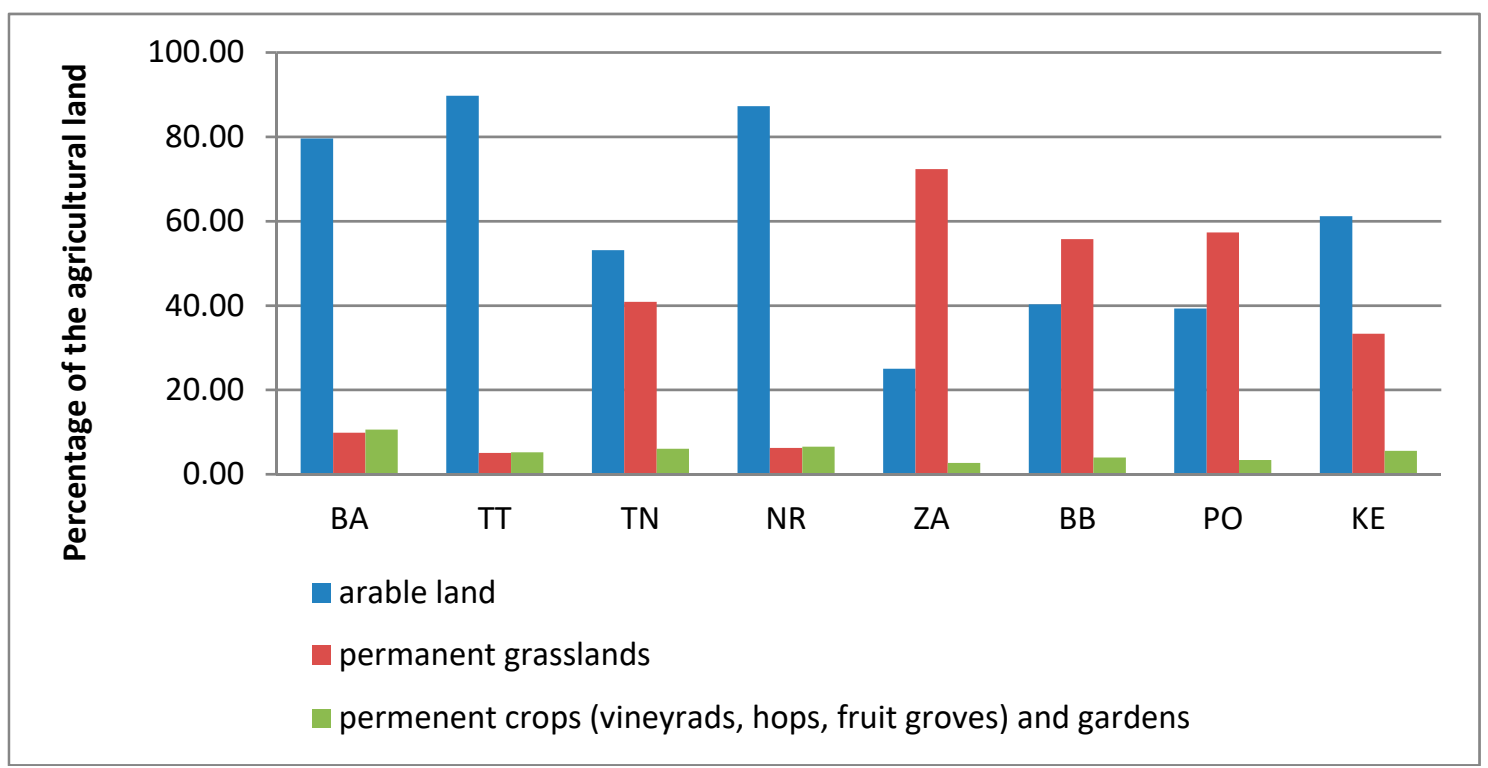

Figure 2. Structure of agricultural land by regions (NUTS III) in 2016.Source: own calculation on the basis of data from Geodesy, Cartography, and Cadastre Authority of Slovak Republic, 2017 (explanation of remarks: Bratislava region (BA), Trnava region (TT), Trenčín region (TN), Nitra region (NR), Žilina region (ZA), Banská Bystrica region (BB), Prešov region (PO), Košice region (KE)).

During the period under study of 2001-2016, the structure of the crops cultivated on the arable land changed (Table 2).

Table 2. Development of the crop diversity in Slovakia 2001-2016 as a percentage of whole crop area.

\begin{tabular}{lrrrr}
\hline & $\mathbf{2 0 0 1}$ & $\mathbf{2 0 0 6}$ & $\mathbf{2 0 1 1}$ & $\mathbf{2 0 1 6}$ \\
\hline Cereals & 60.36 & 55.05 & 54.32 & 56.24 \\
Legumes & 1.14 & 1.35 & 0.64 & 0.94 \\
Root crops & 4.19 & 3.57 & 2.13 & 2.24 \\
Industrial crops & 13.16 & 19 & 19.37 & 19.09 \\
Vegetable & 1 & 0.7 & 0.75 & 0.73 \\
Fodder crops & 19.54 & 18.27 & 20.79 & 17.47 \\
Others & 0.61 & 2.06 & 2 & 3.29 \\
\hline
\end{tabular}

The development of the crop diversity recorded in Table 2 shows that it decreased. The acreage of legumes, root crops (e.g., sugar beets, potatoes), and vegetables permanently decreased. Conversely, the acreage of industrial crops showed remarkable increases. The category "others" includes flowers, seeds for sowing, and land abandonment. Land abandonment comprises the main share of the category "others". The results indicate that specialization and crop homogeneity increased during the period under study. Cereals, industrial crops, and fodder crops are the most popular crops on the arable land. This means that approximately one-third of all arable land in Slovakia is used for the cultivation of crops which are not used for human foods, despite the fact that the food self-sufficiency of Slovakia is very low $[40,41]$.

\subsection{Regional Disparities of Crop Diversity in Slovakia}

The authors suppose that crop diversity is mainly dependent on soil quality and fertility, which differs from one region to another. The region is considered a NUTS III region as described in Table 1. The most fertile soil is situated in the Bratislava region, the Trnava region, the Nitra region, and the Košice region. The northern regions such as the Žilina region and the Prešov region have the poorest soil fertility. The soil quality in each region can be expressed by the administrative land prices 
stipulated by natural indicators, including the indicators of soil quality and fertility. The average administrative land prices indicating the soil quality and fertility of each region are described in Figure 3.

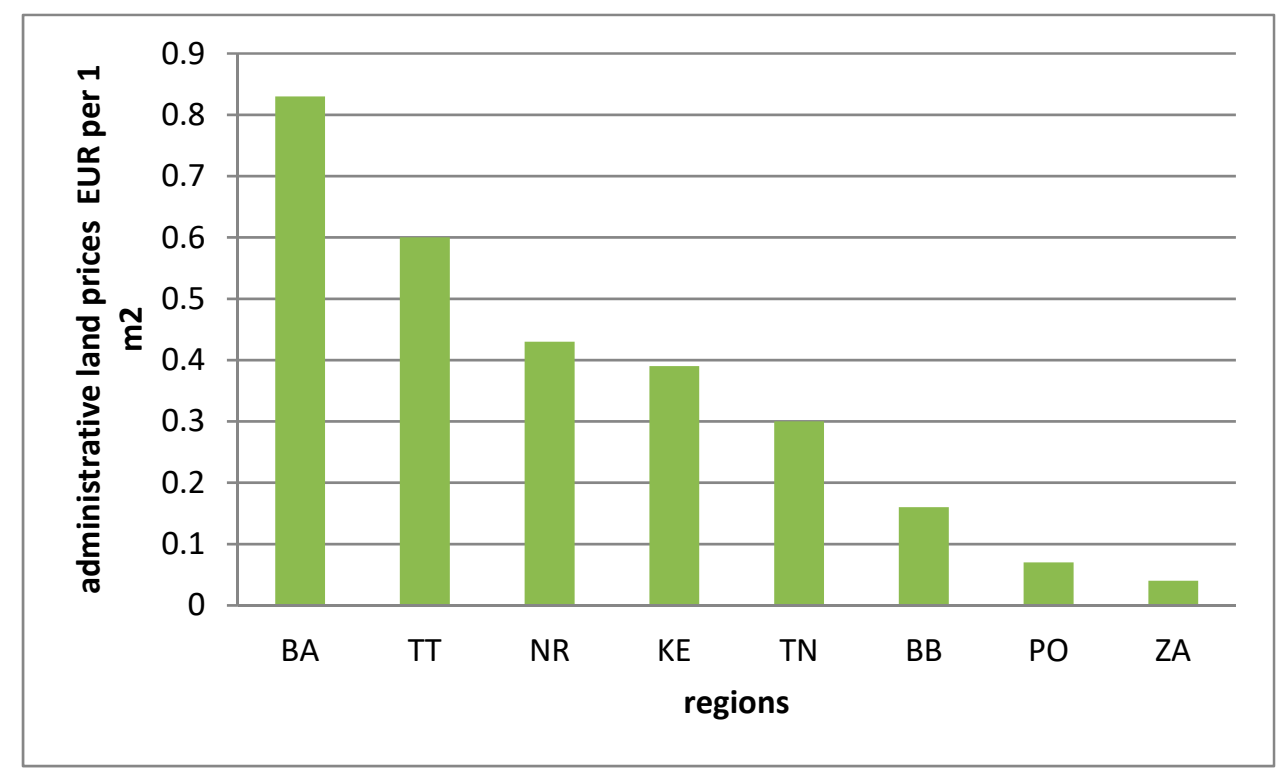

Figure 3. Average administrative land prices in particular regions of Slovakia.Source: own calculation on the basis of data from the Act no. 528/2004 Coll. on local taxes and fees for communal waste (explanation of remarks: Bratislava region (BA), Trnava region (TT), Trenčín region (TN), Nitra region (NR), Žilina region (ZA), Banská Bystrica region (BB), Prešov region (PO), Košice region (KE)).

Significant differences in crop diversity were, therefore, expected between the regions of Slovakia. Crop diversity was quantified by Shannon's equitability index as described in the methodology of this paper. The means and standard deviation of Shannon's equitability crop diversity index (the "crop diversity index") in the different regions of Slovakia are documented in Table 3. In addition, the table lists changes in the crop diversity index in 2011 (a year selected from the CAP period of 2007-2013), 2014 (the year when the new program period of 2014-2020 was implemented), and 2016 (a year selected from the CAP period of 2014-2020).

Table 3. Crop diversity index in the particular regions (NUTS III) of Slovakia in 2011-2016.

\begin{tabular}{lrrrrrr}
\hline Year & \multicolumn{2}{c}{$\mathbf{2 0 1 1}$} & \multicolumn{2}{c}{$\mathbf{2 0 1 4}$} & \multicolumn{2}{c}{$\mathbf{2 0 1 6}$} \\
\hline Descriptive Statistics & Mean & $\begin{array}{l}\text { Standard } \\
\text { Deviation }\end{array}$ & Mean & $\begin{array}{l}\text { Standard } \\
\text { Deviation }\end{array}$ & Mean & $\begin{array}{l}\text { Standard } \\
\text { Deviation }\end{array}$ \\
\hline Bratislava & 0.46 & 0.06 & 0.47 & 0.06 & 0.43 & 0.05 \\
Banská Bystrica & 0.40 & 0.06 & 0.33 & 0.06 & 0.36 & 0.05 \\
Košice & 0.42 & 0.04 & 0.43 & 0.04 & 0.40 & 0.04 \\
Nitra & 0.51 & 0.04 & 0.50 & 0.04 & 0.50 & 0.03 \\
Prešov & 0.30 & 0.06 & 0.27 & 0.05 & 0.29 & 0.06 \\
Trenčín & 0.36 & 0.06 & 0.39 & 0.06 & 0.37 & 0.07 \\
Trnava & 0.47 & 0.06 & 0.50 & 0.04 & 0.50 & 0.03 \\
Žilina & 0.33 & 0.05 & 0.23 & 0.04 & 0.25 & 0.06 \\
Kruskal-Wallis statistics & & 44.87 & & 76.91 & & 72.65 \\
$p$-Value & & 0.00 & & 0.00 & & 0.00 \\
\hline
\end{tabular}

The highest crop diversity index was recorded in the regions with the most fertile land: the Trnava region, the Bratislava region, and the Nitra region. The regions with the poorest soil quality had 
on average the smallest crop diversity indexes. The differences among the regions are statistically significant (with a $p$-value $<0.05$ ).

In most of the regions, the crop diversity index decreased in the period under study. There were only two exceptions: the Trnava region and the Trenčín region; however, there was also stagnation or decline of the crop diversity index in the last two years (2014 and 2016).

In addition, the statistically significant differences among regional crop diversity were tested. The Kruskal-Wallis test was used due to the smaller groups of observed units in some regions. The statistically significant differences are documented in Table 4.

Table 4. Statistically significant differences of crop diversity in the regions of Slovakia in 2016.

\begin{tabular}{|c|c|c|c|c|}
\hline Region & \multicolumn{4}{|c|}{ Multiple Range Test } \\
\hline Žilina & $x$ & & & \\
\hline Prešov & $x$ & $X$ & & \\
\hline BanskáBystrica & & & $x$ & \\
\hline Trenčín & & $X$ & $x$ & \\
\hline Košice & & & $x$ & \\
\hline Bratislava & & & $x$ & \\
\hline Trnava & & & & $x$ \\
\hline Nitra & & & & $x$ \\
\hline
\end{tabular}

According to the obtained results, it was possible to create three groups of regions which included similar intra-groups and statistically different inter-groups in relation to the crop diversity. The first group comprised the regions with the highest crop diversity index: the Nitra region and the Trnava region. The second group included the Bratislava region, the Banská Bystrica region, the Košice region, and the Trenčín region. The third group included the regions with the poorest soil quality: the Prešov region and the Žilina region. The results confirm that the geographical location of an agricultural holding is an important factor of crop diversity. Geographical location was, therefore, included within the econometric model as a dummy variable. The benchmark dummy variable was the first group of regions. These groups were used due to the similarities within them and to decrease the number of dummy variables (eight regions).

\subsection{Impact of CAP Payments on Crop Diversity in Slovakia}

The CAP payments were the main variable of interest in the econometric models used in this paper. The positive regressive coefficient should indicate that the crop diversity increases with higher $\mathrm{CAP}$ payments. Other variables of particular interest were the legal structure of the farm, the distance from the big city, the crop area acreage, the education of the manager, and membership in farmers' associations. The remaining variables were included due to the higher predictability of the models.

The results of the four estimated models are presented in Table 5 for the OLS regression and TOBIT regression. We focused on the interpretation of the parameters of the first model specification, while the remaining models were used to help compare the results to confirm or refute the results of the first model. All models were created in GRETL. Model 1 represents the OLS regression where the heteroskedasticity of model was assessed by the Breusch-Pagan test. Model 2 represents the TOBIT model due to the censured dependent variable. The remaining models are variations of Model 1 and Model 2. They are different in that they include only the significant variables from the previous models. 
Table 5. Econometric models with dependent variable of crop diversity index.

\begin{tabular}{|c|c|c|c|c|}
\hline Variables & Model 1 & Model 2 & Model 3 & Model 4 \\
\hline SAPS & $-0.363 \times 10^{-8 * * *}$ & $-0.363 \times 10^{-8 * * *}$ & $-0.355 \times 10^{-8 * * *}$ & $-0.355 \times 10^{-8 * * *}$ \\
\hline Greening & $0.997 \times 10^{-9}$ & $0.997 \times 10^{-9}$ & & \\
\hline ANC & $0.470 \times 10^{-8 * *}$ & $0.470 \times 10^{-8 * *}$ & $0.481 \times 10^{-8 * *}$ & $0.481 \times 10^{-8 * *}$ \\
\hline AES & $0.968 \times 10^{-9}$ & $0.968 \times 10^{-9}$ & & \\
\hline $\mathrm{ECO}$ & $-0.461 \times 10^{-8}$ & $-0.461 \times 10^{-8}$ & & \\
\hline WELFARE & $0.11 \times 10^{-7 * *}$ & $0.108 \times 10^{-7 * *}$ & $0.994 \times 10^{-8 *}$ & $0.994 \times 10^{-8 *}$ \\
\hline Distance from the city & $0.629 \times 10^{-4}$ & $0.629 \times 10^{-4}$ & & \\
\hline Irrigated agricultural land & $0.200 \times 10^{-4 * * *}$ & $0.200 \times 10^{-4 * * *}$ & $0.199 \times 10^{-4 * * *}$ & $0.199 \times 10^{-4 * * *}$ \\
\hline Land used for the organic agriculture & $-0.849 \times 10^{-7}$ & $-0.849 \times 10^{-7}$ & & \\
\hline Number of employees & $-0.587 \times 10^{-4 *}$ & $-0.587 \times 10^{-4 * *}$ & $-0.636 \times 10^{-4 * *}$ & $-0.636 \times 10^{-4 * *}$ \\
\hline Total crop area & $0.129 \times 10^{-4 * * *}$ & $0.129 \times 10^{-4 * * *}$ & $0.137 \times 10^{-4 * * *}$ & $0.137 \times 10^{-4 * * *}$ \\
\hline $\begin{array}{l}\text { Revenues from agricultural (crops and } \\
\text { animal) production share in total revenues }\end{array}$ & $-0.409 \times 10^{-6}$ & $-0.409 \times 10^{-6}$ & & \\
\hline $\begin{array}{l}\text { Revenues from the organic agriculture } \\
\text { share in total revenues }\end{array}$ & $-0.013^{* * *}$ & $-0.013^{* * *}$ & $-0.016^{* * *}$ & $-0.015^{* * *}$ \\
\hline Total revenues share in total costs & $-0.871 \times 10^{-6 * *}$ & $-0.871 \times 10^{-6 * *}$ & $-0.854 \times 10^{-6 * *}$ & $-0.854 \times 10^{-6 * *}$ \\
\hline Stocks share in total costs & $-0.592 \times 10^{-6 *}$ & $-0.592 \times 10^{-6 *}$ & $-0.644 \times 10^{-6 * *}$ & $-0.644 \times 10^{-6 * *}$ \\
\hline Stocks share in total revenues & $0.302 \times 10^{-7}$ & $0.302 \times 10^{-7}$ & & \\
\hline $\begin{array}{l}\text { Revenues from the animal production share } \\
\text { in revenues of the agricultural production }\end{array}$ & $-0.234 \times 10^{-4}$ & $-0.234 \times 10^{-4}$ & & \\
\hline \multicolumn{5}{|l|}{ Region } \\
\hline 1stgroup & Benchmark & & & \\
\hline 2nd group & $-0.592 \times 10^{-1 * * *}$ & $-0.592 \times 10^{-1 * * *}$ & $-0.637 \times 10^{-1 * * *}$ & $-0.637 \times 10^{-1 * * *}$ \\
\hline 3rd group & $-0.819 \times 10^{-1 * * *}$ & $-0.819 \times 10^{-1 * * *}$ & $-0.858 \times 10^{-1 * * *}$ & $-0.858 \times 10^{-1 * * *}$ \\
\hline \multicolumn{5}{|l|}{ Legal form } \\
\hline Business company & Benchmark & & & \\
\hline Cooperative & $0.109 * * *$ & $0.109^{* * *}$ & $0.112 * * *$ & $0.112 * * *$ \\
\hline Individual farmer & $0.028 *$ & $0.028 *$ & $0.032 * *$ & $0.032 * *$ \\
\hline \multicolumn{5}{|l|}{ Education } \\
\hline Manager only with agricultural experiences & Benchmark & & & \\
\hline $\begin{array}{l}\text { Manager with some courses from } \\
\text { agriculture }\end{array}$ & -0.015 & -0.015 & & \\
\hline $\begin{array}{l}\text { Manager with at least } 2 \text { years of agricultural } \\
\text { education }\end{array}$ & 0.024 & 0.024 & & \\
\hline $\begin{array}{l}\text { Manger with university education of } \\
\text { agriculture, silviculture, veterinary, } \\
\text { horticulture, or agricultural engineering }\end{array}$ & 0.011 & 0.011 & & \\
\hline $\begin{array}{l}\text { Manager with university education outside } \\
\text { of agriculture }\end{array}$ & -0.020 & -0.020 & & \\
\hline \multicolumn{5}{|l|}{ Membership in the farmers' associations } \\
\hline Non-member & Benchmark & & & \\
\hline Member & 0.018 & 0.018 & & \\
\hline Constant & $0.465^{* * *}$ & $0.465^{* * *}$ & $0.471^{* * *}$ & $0.471^{* * *}$ \\
\hline$R^{2}$ & 0.335 & - & 0.320 & - \\
\hline Adjusted $R^{2}$ & 0.301 & - & 0.302 & - \\
\hline
\end{tabular}

\footnotetext{
$*, * *$, and ${ }^{* * *}$ represents the level of significance on $10 \%, 5 \%$, and $1 \%$.
}

The results of Models 1-4 indicate that there are no significant differences between OLS models (Model 1 and Model 3) and TOBIT models (Model 2 and Model 4). The regression coefficients are very similar. There was only one difference in the statistical significance of the variable "number of employees". In the OLS model, this variable is not significant. In the TOBIT model, the number of employees is statistically significant at $5 \%$.

The first pillar of CAP includes mainly the direct payments referred to as the single area payments scheme (SAPS) to stabilize farm income due to volatile market prices and weather conditions. According to Models 1-4, it is the statistically significant variable with regard to the crop diversity index; however, the relationship is negative. This means that, if the SAPS variable increases by one euro, the crop diversity index is expected to decrease on average by $0.363 \times 10^{-8}$ percentage points. This study reaches a similar conclusion to Reger et al., who confirmed the homogenization of farmland structure in all of their scenarios of direct transfer payments [25]. Similarly, Miettinen et al. concluded that, at the landscape level, those policy reforms in which support is decoupled change land use and decrease the diversity of agricultural land-cover classes [42]. It can be concluded that direct payments homogenize crop diversity on the arable land in Slovakia. The policy of direct payments does not motivate the farmers to improve or at least maintain the land and crop diversity. In Slovakia, most 
farmers cultivate a maximum three or four crops such as wheat, barley, maize, or oilseeds (Brassica napus or sunflower). The most preferred crop is wheat, with associated crop areas still increasing yearly (in 2011, wheat occupied 28,60\% of arable land (404877 hectares of wheat); in 2016, the wheat is cultivated on $35,95 \%$ of arable land (506815 hectares of wheat)). On the other hand, Capitanio et al. found a positive relationship between direct payments and the crop diversity of cereal-producing farms in Italy over the period 2004-2010 that was decoupled from production (single farm payments) [22]. However, in Slovakia, the SAPS still applies.

The second pillar of the CAP is related to rural development with the aim of achieving balanced rural development and sustaining the agricultural holdings that are environmentally friendly and competitive on the agricultural market. There are relatively very few studies that evaluate the effects of the second pillar on crop diversity. Capitanio et al. concluded that the coefficient on the amount of support received by farmers from the second pillar was not statistically significant over the period 2004-2010 in Italy [22]. In Slovakia, this study found that the second pillar of the CAP payments, particularly payments for less favorable areas and animal welfare, represents the most important payments with positive effects on the crop diversity in Slovakia over the period 2015-2016. This means that, if the variables ANC or WELFARE increase, the crop diversity index is also expected to increase (Table 5). The estimate of the variable ANC is slightly higher than the estimate of the SAPS variable in absolute values; however, the estimate of the WELFARE variable is much lower than the estimate of SAPS or ANC variables in absolute values. It seems that the second pillar is more important for the sustainability of crop diversity.

Other statistically significant indicators are irrigated area of land, total crop area, revenues from the organic farming, geographical location, and the legal structure of agricultural holdings with positive or negative relationships. In the last few decades, the southern regions of Slovakia suffered from a lack of rainfall. Accordingly, the irrigation of the agricultural land became increasingly important. Models 1-4 indicate that irrigated areas of agricultural land help increase or at least maintain crop diversity. This is a trend not only in Slovakia, but also in other countries; for instance, Monteleone et al. stated that it seems to be established that crop diversity is a feasible target only if a sufficient water supply for irrigation is available [11].

Total crop area is a variable which substitutes farm size. Models 1-4 provide evidence that farm size expressed by the total crop area has a positive relationship with crop diversity. The estimate of total crop area is slightly lower than the estimate of irrigation. According to the literature review, there is no consensus on the effects of this variable. Our results confirm the results of studies [30-34] that there is strong indication of a positive relationship between diversification and farm size.

It was found that geographical location was one of the statistically significant variables in the model. The previous section indicates the statistically significant differences of crop diversity between the regions of Slovakia. The regions (NUTS III) were divided into three groups (Group 1: the Nitra region and the Trnava region; Group 2: the Bratislava region, the Banská Bystrica region, the Košice region, and the Trenčín region; Group 3: the Prešov region and the Žilina region). The three groups of regions also indicate the soil quality. The third group comprises the regions with the poorest soil quality, and the first group comprises the regions with the best soil quality. Models 1-4 provide evidence that the regions of the second and third group decrease the crop diversity depending on the soil quality. If a land plot is located in the regions of the third group, the crop diversity index is smaller than a land plot located in the regions of the second group. The statistically significant effects of geographical location were confirmed in the studies of van der Sluis et al. [28], Sichoongwe et al. [34] and Benin et al. [35].

A statistically significant relationship was also demonstrated between crop diversity and the legal structure of the agricultural holdings. There are typically three legal structures of agricultural holdings in Slovakia. Businesses predominantly in the form of limited liability companies are the most popular legal structure, and they were stipulated as a benchmark legal structure of agricultural holdings. The highest level of crop diversity is achieved by cooperatives as a legal structure of agricultural 
holdings that are both traditional and typical in Slovakia. Individual farmers as ordinary people doing business in agriculture are more diversified than business companies; however, the regression coefficient is statistically significant only in Models 3 and 4 at $5 \%$. There are specific legal structures of agricultural holdings in Slovakia and, as such, it is possible to compare our analysis with the results obtained in the literature.

Based on the research mentioned in the literature overview, a statistically significant effect of many other variables on crop diversity was expected, such as the distance from the city, the education of the manager, the number of employees, or membership in farmers' associations. The obtained regression coefficients are not statistically significant in any model with the one exception related to the number of employees. There is a negative relationship between crop diversity and the number of employees. This factor was determined to be statistically significant by the TOBIT model (Models 2 and 4) and OLS Model 3, while all models confirmed the negative relationship.

\section{Conclusions}

Crop diversity has an important role in sustainable agro-ecosystems. Moreover, it helps diversify the risks associated with agricultural business. In this study, the crop diversity of agricultural holdings in particular regions (NUTS III) in Slovakia was analyzed, and the impact of the CAP payments (e.g., SAPS, greening, ANC, agri-environmental schemes, payments for organic agriculture, and payments for animal welfare) on crop diversity was identified. From the results of the regional comparison of crop diversity, it can be concluded that there are regional disparities. The highest crop diversity is typical for the regions with the best soil quality. The regions were segmented into three groups. The first group was created by the regions with the highest crop diversity index: the Nitra region and the Trnava region. The second group included the Bratislava region, the Banská Bystrica region, the Košice region, and the Trenčín region. The third group included the regions with the poorest soil quality: the Prešov region and the Žilina region. The results confirm that the geographical location of an agricultural holding is an important factor with regard to crop diversity. Geographical location was accordingly included within the econometric model as a dummy variable. The results of the econometric models demonstrate that some of the CAP payments have an impact on the crop diversity; these were predominantly the SAPS payments, which were found to have a negative effect on crop diversity, and ANC payments and animal welfare payments, which were found to have positive effects. It can be concluded that the second pillar of the CAP is able to improve or at least maintain crop diversity in Slovakia. Other factors affecting crop diversity are irrigation, the total crop area corresponding to the farm size, and geographical location, including the soil quality and the legal structure of agricultural holdings. Conversely, distance from the city, the education of the manager, and membership in farmers' associations are not important factors for crop diversity in Slovakia.

Author Contributions: Conceptualization, J.L.; methodology, J.L. and Z.L.; validation, L'.R. and I.T.; formal analysis, J.L.; investigation, L'.R. and A.B.; resources, L'.R. and A.B.;data curation, Z.L.; writing-original draft preparation, J.L.; writing-review andediting, L'.R., I.T., Z.L., and A.B.; project administration, L'.R.; funding acquisition, L'.R.

Funding: This research received no external funding.

Acknowledgments: This work was supported by the Grant Agency FESRD projects No. 7/2017, “The impact of CAP supportive mechanism on the market with agricultural land in Slovakia".

Conflicts of Interest: The authors declare no conflict of interest.

\section{References}

1. Council of Europe. European Landscape Convention, Florence, 20.X. 2000; Council of Europe: Strasbourg, France, 2000; p. 7. Available online: https://rm.coe.int/1680080621 (accessed on 10 May 2018).

2. Brady, M.; Sahrbacher, C.; Kellermann, K.; Happe, K. An agent-based approach to modeling impacts of agricultural policy on land use, biodiversity and ecosystem services. Landsc. Ecol. 2012, 27, 1363-1381. [CrossRef] 
3. Billeter, R.; Liira, J.; Bailey, D.; Arens, P.; Augenstein, I.; Aviron, S.; Baudry, J.; Bukacek, R.; Burel, F.; Cerny, M.; et al. Indicators for biodiversity in agricultural landscapes: A pan-European study. J. Appl. Ecol. 2008, 45, 141-150. [CrossRef]

4. Kleijn, D.; Hohler, F.; Báldi, A.; Batáry, P.; Concepción, E.D.; Clough, Y.; Díaz, M.; Gabriel, D.; Holzschuh, A.; Knop, E.; et al. On the relationship between farmland biodiversity and land-use intensity in Europe. Proc. R. Soc. B 2009, 276, 903-909. [CrossRef] [PubMed]

5. Fehér, A.; Končeková, L.; Glemnitz, M.; Berger, G.; Holger, P.; Herzon, I. Maintaining and Promoting Biodiversity. In Sustainable Agriculture; Baltic University Press: Uppsala, Sweden, 2012; pp. 371-387.

6. Lefebvre, M.; Espinosa, M.; Gomez y Paloma, S. The Influence of the Common Agricultural Policy on Agricultural Landscapes; JRC Scientific and policy reports; European Commission, Joint Research Centre: Brussels, Belgium, 2012.

7. Batáry, P.; Dicks, L.V.; Kleijn, D.; Sutherland, W.J. The role ofagri-environment schemes in conservation and environmental management. Conserv. Biol. 2015, 29, 1006-1016. [CrossRef] [PubMed]

8. Heal, G. Nature and the Marketplace: Capturing the Value of Ecosystem Services; Island Press: Washington, DC, USA, 2000; pp. 203-2000.

9. Lin, B.B. Resilience in agriculture through crop diversification: Adaptive management for environmental change. BioScience 2011, 61, 183-193. [CrossRef]

10. Davis, A.S.; Hill, J.D.; Chase, C.A.; Johanns, A.M.; Liebman, M. Increasing cropping system diversity balances productivity, profitability and environmental health. PLoS ONE 2012, 7, e47149. [CrossRef] [PubMed]

11. Monteleone, M.; Cammerino, A.R.B.; Libutti, A. Agricultural "greening" and cropland diversification trends: Potential contribution of agroenergy crops in Capitanata (South Italy). Land Use Policy 2018, 70, 591-600. [CrossRef]

12. Bowman, M.S.; Zilberman, D. Economic factors affecting diversified farming systems. Ecol. Soc. 2013, 18, 33-47. [CrossRef]

13. Donfouet, H.P.P.; Barczak, A.; Détang-Dessendre, C.; Maigné, E. Crop Production and Crop Diversity in France: A Spatial Analysis. Ecol. Econ. 2017, 134, 29-39. [CrossRef]

14. Robinson, R.A.; Sutherland, W.J. Post-war changes in arable farming and biodiversity in Great Britain. J. App. Ecol. 2002, 39, 157-176. [CrossRef]

15. Petit, S.; Elbersen, B. Assessing the risk of impact of farming intensification on calcareous grasslands in Europe: A quantitative implementation of the MIRABEL framework. AMBIO 2006, 35, 297-303. [CrossRef] [PubMed]

16. Fehér, A. VegetationHistory and CulturalLandscapes: CaseStudiesfromSouth.-West Slovakia; Springer International Publishing: Cham, Germany, 2018; 306p.

17. European Commission. The Reform of the Cap Towards 2020. Consultation Document for Impact Assessment; European Commission: Brussels, Belgium, 2013; 18p. Available online: https:/ / ec.europa.eu/agriculture/sites/ agriculture/files / cap-post-2013/consultation/consultation-document_en.pdf (accessed on 11 May 2018).

18. Leventon, J.; Schaal, T.; Velten, S.; Dänhardt, J.; Fischer, J.; Abson, D.J.; Newig, J. Collaboration or fragmentation. Biodiversity management through the common agricultural policy. Land Use Policy 2017, 64, 1-12. [CrossRef]

19. Hauck, J.; Schleyer, C.; Winkler, K.J.; Maes, J. Shades of greening: Reviewingthe impact of the new EU agricultural policy on ecosystem services. Chang. Adapt. Socioecol. Syst. 2014, 1, 51-62. [CrossRef]

20. Pe'er, G.; Dicks, L.V.; Visconti, P.; Arlettaz, A.; Báldi, T.G.; Benton, S.; Collins, M.; Dieterich, R.D.; Gregory, F.; Hartig, K.; et al. EU agricultural reform fails onbiodiversity. Science 2014, 344, 1090-1092. [CrossRef] [PubMed]

21. Davey, C.M.; Vickery, J.A.; Boatman, N.D.; Chamberlain, D.E.; Parry, H.R.; Siriwardena, G.M. Assessing the impact of entry level stewardship onlowland farmland birds in England. Ibis 2010, 152, 459-474. [CrossRef]

22. Capitanio, F.; Gatto, E.; Millemaci, E. CAP payments and spatial diversity in cereal crops: An analysis of Italian farms. Land Use Policy 2016, 54, 574-582. [CrossRef]

23. Chiron, F.; Princé, K.; Paracchini, M.L.; Bulgheroni, C.; Jiguet, F. Forecasting the potential impacts of CAP-associated land use changes on farmland birds at the national level. Agric. Ecosyst. Environ. 2013, 176, 17-23. [CrossRef]

24. Renwick, A.; Janson, T.; Verburg, P.H.; Revoredo-Giha, C.; Britz, W.; Gocht, A.; McCracken, D. Policy reform and agricultural land abandonment in the EU. Land Use Policy 2013, 30, 446-457. [CrossRef] 
25. Reger, B.; Sheridan, P.; Simmering, D.; Otte, A.; Waldhardt, R. Potential effects of direct transfer payments on farmland habitat diversity in a marginal European landscape. Environ. Manag. 2009, 43, 1026-1038. [CrossRef] [PubMed]

26. Piorr, A.; Ungaro, F.; Ciancaglini, A.; Happe, K.; Sahrbacher, A.; Sattler, C.; Uthes, S.; Zander, P. Integrated assessment of future CAP policies: Land use changes, spatial patterns and targeting. Environ. Sci. Policy 2009, 12, 1122-1136. [CrossRef]

27. Jambor, A.; Harvey, D. Review of the Challenges of CAP Reform; Report Discussion Paper Series; Centre for Rural Economy, School of Natural and Environmental Sciences, Newcastle University: Newcastle upon Tyne, UK, 2010; 27p, Available online: http:/ /www.ncl.ac.uk/cre/publish/discussionpapers/pdfs / dp27JamborHarvey.pdf (accessed on 14 September 2018).

28. Van der Sluis, T.; Pedroli, B.; Kristensen, S.B.P.; Cosor, G.L.; Pavlis, E. Changing land use intensity in Europe-Recent processes in selected case studies. Land Use Policy 2016, 57, 777-785. [CrossRef]

29. White, T.; Irwin, G. Farm size and specialization. In Size Structure and Future of Farms Ames; Ball, G., Heady, E., Eds.; Iowa State University Press: Iowa, IA, USA, 1972.

30. Pope, R.D.; Prescott, R. Diversification in relation to farm size and other socioeconomic characteristics. Am. J. Agric. Econ. 1980, 62, 554-559. [CrossRef]

31. McNally, S. Farm diversification in England and wales-what can we learn from farm business survey. J. Rural Stud. 2001, 17, 247-257. [CrossRef]

32. Culas, R. Causes of farm diversification over time: An Australian perspective on an Eastern Norway model. AFMB J. 2006, 3, 1 .

33. Weiss, C.R.; Bringlauer, W. Determinants and Dynamics of Farm. Diversification; FE Working Paper; University of Kiel: Kiel, Germany, 2000; 15p. Available online: https://ageconsearch.umn.edu/record/24929/files/ cp02we35.pdf (accessed on 14 September 2018).

34. Sichoongwe, K.; Mapemba, L.; Ng'ong'ola, D.; Tembo, G. The Determinants and Extent of Crop Diversification among Smallholder Farmers. A Case Study of Southern Province Zambia. J. Agric. Sci. 2014, 6, 150-159. [CrossRef]

35. Benin, S.; Smale, M.; Gebremedhin, B.; Pender, J.; Ehui, S. The economic determinants of cereal crop diversity on farms in the Ethiopian Highlands. Agric. Econ. 2004, 31, 197-208. [CrossRef]

36. Mishra, A.K.; El-Osta, H.S.; Sandretto, C.L. Factors affecting farm enterprise diversification. Agric. Financ. Rev. 2004, 64, 151-166. [CrossRef]

37. Banerjee, D.; Bhattacharyya, R. Problems of crop diversification in West Bengal. In Diversification of Agriculture in Eastern India; Ghosh, M., Sarkar, D., Roy, B.C.H., Eds.; Springer: New Delphi, India, 2015; pp. 155-165.

38. Acharya, S.P.; Basavaraja, H.; Kunnal, L.B.; Mahajanashetti, S.B.; Bhat, A.R.S. Crop diversification in Karnataka. An Economic analysis. Agric. Econ. Res. Rev. 2011, 24, 351-357.

39. Shannon, C.E.A. Mathematical theory of communication. Bell Syst. Tech. J. 1948, 27, 379-423. [CrossRef]

40. Krížová, S.; Buday, Š. Socio-economic aspects of food consumption in Slovakia: Overview of contemporary issues. J. Food Nutr. Res. 2015, 54, 21-30.

41. Slaboch, J.; Kotyza, P. Comparison of self-sufficiency of selected types ofmeat in the Visegrad countries. J. Cent. Eur. Agric. 2016, 17, 793-814. [CrossRef]

42. Miettinen, A. On diversity effects of alternative agricultural policy reforms in Finland: An agricultural sector modelling approach. Agric. Food Sci. 2004, 13, 229-246. [CrossRef]

(C) 2019 by the authors. Licensee MDPI, Basel, Switzerland. This article is an open access article distributed under the terms and conditions of the Creative Commons Attribution (CC BY) license (http://creativecommons.org/licenses/by/4.0/). 